\title{
Optimisation of the liquid-liquid extraction of soybean oil using a binary mixture ${ }^{1}$
}

\author{
Otimização da extração líquido-líquido de óleo de soja com mistura binária
}

\author{
Glêndara Aparecida de Souza Martins ${ }^{2 *}$ e Joênes Mucci Peluzio²
}

\begin{abstract}
The soybean has been widely studied due to its constituents and to their application. Authors have pointed out that its composition can vary, with its use frequently taking the form of oil. The oil extraction process, which is in constant application in the market, consists of the use of extraction solvents, with hexane being one of the most used; however the fact that this comes from non-renewable sources has aroused interest in its replacement. As a result, ethanol has been seen as an alternative solvent, despite increasing the cost of the process. This study therefore aims to evaluate the composition of three soybean cultivars planted in the region of Palmas, in the state of Tocantins, Brazil, and to optimise oil extraction from the beans through the use of a binary mixture of ethanol and hexane. The cultivars displayed high protein and lipid potential. The extraction time and temperature proved influential in the process. Ethanol, when present in greater quantity in the mixture, with an increase in temperature, caused an increase in the levels of extracted oil.
\end{abstract}

Key words: Extraction Solvent. Temperature. Time.

RESUMO - A soja é amplamente estudada em função dos seus constituintes e sua aplicabilidade. Autores apontam que sua composição é variável e seu uso frequente se dá na forma de óleo. O processo de extração de óleo, em constante aplicação no mercado, consiste no uso de solventes extratores, sendo o hexano um dos mais utilizados; porém, o fato de se originar de fontes não renováveis tem despertado o interesse por sua substituição. Nesse contexto, o etanol vem se apresentando como um solvente alternativo apesar de onerar o custo do processo. Assim, o presente trabalho tem por objetivo avaliar a composição de três cultivares de soja plantados na região de Palmas-Tocantins e otimizar a extração do óleo desses grãos através do uso de uma mistura binária de etanol e hexano. Os cultivares apresentaram alto potencial de proteína e lipídeos. O tempo e a temperatura de extração mostraram-se influentes no processo. O etanol, presente em maior quantidade na mistura, e o aumento na temperatura provocaram um acréscimo no teor de óleo extraído.

Palavras-chave: Solvente Extrator. Temperatura. Tempo.

\footnotetext{
*Autor para correspondência

${ }^{1}$ Recebido para publicação em 22/09/2012; aprovado em 11/10/2014

Parte da Tese de Doutorado da primeira autora apresentada ao Programa de Pós-Graduação em Biodiversidade e Biotecnologia da rede BIONORTE

${ }^{2}$ Departamento de Engenharia de Alimentos, Laboratório de Microbiologia e Bioprocessos, Campus Universitário de Palmas, Universidade Federal do Tocantins, Avenida NS 15, 109 Norte, bloco 2 sala 07, Plano Diretor Norte Palmas-TO, Brasil, 77.001-090, glendarasouza@uft. edu.br, joenesp@mail.uft.edu.br
} 


\section{INTRODUCTION}

Defined by the Ministry of Agriculture as the Brazilian crop that has most increased in the last three decades, the soybean (Glycine max L.) corresponds to approximately $49 \%$ of the area of the country planted with grain (BRASIL, 2011). According to data from Conab (Companhia Nacional de Abastecimento), estimated productivity for the state of Tocantins is $2.783 \mathrm{~kg} / \mathrm{ha}$ for the 2012/2013 crop, being therefore considered one of the most productive states in the north of Brazil (BRASIL, 2013).

Oil from the soybean is a product which is widely commercialised due to its many applications, which range from its use in the food industry to the production of biofuels (BEHRENS; SILVA, 2004).

The use of a crop in a production process, in any area, must effectively meet the long-term market demand (GUARIENTI et al., 2012; TOMAZIN JUNIOR, 2008). Because of this, the extraction of soybean oil is frequently under study due to the range of variables that can influence the productivity of the process, as well as production costs (BRUM; ARRUDA; REGITANO-D'ARCE, 2009; FREITAS et al., 2010; NIMET et al., 2011).

In the industrialisation of oilseeds, solvent extraction is the process most used, and according to Guarienti et al. (2012) has been reported as the most efficient, with extraction capacity varying according to, among other factors, the solvent used, and the extraction time and temperature. Freitas et al. (2010) state that several solvents are capable of extracting the oil from grains, with hexane being the most widely used solvent in the industrial process, having the disadvantage however of coming from non-renewable sources.

Negative aspects associated with the use of hexane have resulted in the search for alternative solvents that do not affect extraction. Accordingly, Correia (2009) points to ethanol as a possible replacement, since its use has always been seen to be environmentally important and its efficiency tested but still questionable due to the high cost of the process of solvent recovery.

This study therefore aims to evaluate the composition of three soybean cultivars planted in the region of Palmas in the state of Tocantins, and to optimise the extraction of oil from these grains through the use of a binary mixture of ethanol and hexane.

\section{MATERIAL AND METHODS}

\section{Preparing and characterising the raw material}

The soybean cultivars M9144RR, TMG1182RR and M7578RR were obtained from germplasm by competitive cultivar testing conducted at the Palmas Campus of the Federal University of Tocantins. Once harvested, the grains were identified and taken in plastic bags to the Laboratory for Microbiology and Bioprocesses of the Federal University of Tocantins. The material was then selected, washed with a neutral detergent, sanitised with chlorine $(50 \mathrm{ppm})$, placed into sealed, plastic containers and stored in a freezer at a temperature of $-18{ }^{\circ} \mathrm{C}$ until used.

To characterise the raw material, the following analyses were carried out in triplicate, following the methodology described by the Instituto Adolfo Lutz (2005): moisture, protein, fibre, ash, glycids, $\mathrm{pH}$ and titratable acidity.

\section{Optimising the soybean oil extraction process}

Oil was extracted from the beans according to the methodology described by the Instituto Adolfo Lutz (2005).

At this stage, a $2^{3}$ full factorial design (levels \pm 1 ) was used, with the addition of three central points (level 0), giving a total of 11 trials (Table 1).

To evaluate the effect of the various factors, the linear model was estimated to include the interaction effect as per Equation 1:

$Y=\beta_{0}+\beta_{1} \chi_{1}+\beta_{2} \chi_{2}+\beta_{3} \chi_{3}+\beta_{12} \chi_{1} \chi_{2}+\beta_{13} \chi_{1} \chi_{3}+\beta_{23} \chi_{2} \chi_{3}+\varepsilon$

where $\beta_{\mathrm{n}}$ are the regression coefficients, $\mathrm{Y}$ is the response in question (yield expressed in \% of extracted oil), $\mathrm{x}_{1}, \mathrm{x}_{2}$ and $\mathrm{x}_{3}$ are the independent coded variables (Time, Temperature and Ethanol/Hexane Ratio ) and $\varepsilon$ is the experimental error.

Table 1 - Experimental design for the soybean oil extraction trials

\begin{tabular}{lcccccc}
\hline \multirow{2}{*}{ Trial } & \multicolumn{3}{c}{ Coded variables } & \multicolumn{4}{c}{ Real variables } \\
\cline { 2 - 7 } & $\mathrm{X} 1$ & $\mathrm{X} 2$ & $\mathrm{X} 3$ & $\mathrm{X} 1(\mathrm{~min})$ & $\mathrm{X} 2\left({ }^{\circ} \mathrm{C}\right)$ & $\mathrm{X} 3(\mathrm{v} / \mathrm{v})$ \\
\hline 1 & +1 & +1 & +1 & 120 & 75 & $60 / 40$ \\
2 & +1 & +1 & -1 & 120 & 75 & $40 / 60$ \\
3 & +1 & -1 & +1 & 120 & 90 & $60 / 40$ \\
4 & +1 & -1 & -1 & 120 & 90 & $40 / 60$ \\
5 & -1 & +1 & +1 & 480 & 75 & $60 / 40$ \\
6 & -1 & +1 & -1 & 480 & 75 & $40 / 60$ \\
7 & -1 & -1 & +1 & 480 & 90 & $60 / 40$ \\
8 & -1 & -1 & -1 & 480 & 90 & $40 / 60$ \\
9 & 0 & 0 & 0 & 300 & 82.5 & $50 / 50$ \\
10 & 0 & 0 & 0 & 300 & 82.5 & $50 / 50$ \\
11 & 0 & 0 & 0 & 300 & 82.5 & $50 / 50$ \\
\hline
\end{tabular}

X1- Reaction time; X2- Reaction temperature; X3 - Ethanol/Hexane Ratio 


\section{Statistical analysis}

The data from the characterisation of the different cultivars were studied by variance analysis (ANOVA) and Tukey's test at $5 \%$ significance $(\mathrm{p} \leq 0.05)$, as per Gomes (2000).

To evaluate the effect of extraction time, temperature and ratio of the binary mixture of ethanol and hexane (independent variables) on the response variable, level of extracted oil, variance analysis (ANOVA) and Tukey's test at $5 \%$ significance $(\mathrm{p} \leq 0.05)$ were employed, as per Gomes (2000); for the optimisation stage, response surface methodology (BOX; DRAPER, 1987) was applied.

\section{RESULTS AND DISCUSSION}

Table 2 shows the composition of the raw material used. The cultivars only displayed statistical differences $(\mathrm{p} \leq 0.05)$ for the values for ash, protein and titratable acidity. According to Pelúzio et al. (2008), the constituents of the soybean are influenced by conditions at sowing, since environmental factors such as temperature and rainfall react with each other and interact with the plant.

The values for $\mathrm{pH}$ and acidity did not show a statistical difference between cultivars. The averages found being similar to those seen by Carvalho et al. (2011).

The composition of the raw materials under study indicates potential in the cultivars when protein and lipid levels are evaluated. Similar results were seen by Martinez et al. (2011) and Moura et al. (2007) for other soybean cultivars in the State of São Paulo.

Table 3 describes the results of the variance analysis of the yield from oil extraction for the three cultivars under study, using the proposed binary mixture.
Extraction time was found to be influential for the majority of cultivars being studied (Table 3 ). Similar results were reported by Zachi (2007) when observing a large yield in the first minutes of soybean oil extraction, with a subsequent reduction over time for some of the samples. Temperature affected the process of oil extraction from the three cultivars, and the interaction between the variables was found to be significant, as can be seen in Table 3 .

Extraction time was found to be influential for the majority of cultivars being studied (Table 3). Similar results were reported by Zachi (2007) when observing a large yield in the first minutes of soybean oil extraction, with a subsequent reduction over time for some of the samples. Temperature affected the process of oil extraction from the three cultivars, and the interaction between the variables was found to be significant.

An increase in the quantity of ethanol in the binary mixture caused greater oil extraction for all the cultivars under study (Figures 1, 2 and 3). According to Freitas et al. (2010), the increased oil extraction for mixtures involving ethanol is due to its ability to extract certain residual lipids, which are mostly made up of saponifiable lipids (phosphatides and free fatty acids), cyclic and aliphatic alcohols and certain unsaponifiable lipids (hydrocarbons and phenols). Similar results were observed by Brum, Arruda and Regitano-D'arce (2009).

When the extraction temperature was analysed, a higher extraction potential was seen at temperatures greater than the boiling point of both hexane and ethanol (Figure 1, 2 and 3). This phenomenon can be explained by the fact that higher temperatures facilitate transit of the solvent, as there is an increase in the kinetic energy and decrease in the viscosity of the ground soybean molecules, which allows for a higher diffusion coefficient than molecules immersed in liquids at lower temperatures.

Table 2 - Physico-chemical characteristics of the soybean cultivars

\begin{tabular}{lccc}
\hline \multirow{2}{*}{ Caracteristic } & \multicolumn{3}{c}{ Cultivar } \\
\cline { 2 - 4 } & TMG1182RR Mean \pm SD & M7578RR Mean \pm SD & M9144RR Mean \pm SD \\
\hline Fibre & $2.59 \mathrm{a} \pm 0.17$ & $2.54 \mathrm{a} \pm 0.53$ & $2.76 \mathrm{a} \pm 0.16$ \\
Moisture & $11.33 \mathrm{a} \pm 1.0$ & $12.84 \mathrm{a} \pm 0.42$ & $12.39 \mathrm{a} \pm 0.96$ \\
Ash & $6.49 \mathrm{a} \pm 0.29$ & $6.65 \mathrm{a} \pm 0.00$ & $6.12 \mathrm{~b} \pm 0.05$ \\
Proteín & $35.23 \mathrm{a} \pm 0.16$ & $36.03 \mathrm{ab} \pm 0.6$ & $36.28 \mathrm{~b} \pm 0.09$ \\
pH & $6.79 \mathrm{a} \pm 0.01$ & $6.86 \mathrm{a} \pm 0.02$ & $6.72 \mathrm{a} \pm 0.07$ \\
Titratable acidity & $3.79 \mathrm{a} \pm 0.52$ & $3.79 \mathrm{a} \pm 0.52$ & $4.83 \mathrm{a} \pm 0.16$ \\
Lipids & $18.41 \mathrm{a} \pm 0.75$ & $19.21 \mathrm{~b} \pm 1.9$ & $18.81 \mathrm{a} \pm 0.27$ \\
Glycids & $16.75 \mathrm{a} \pm 2.6$ & $13.06 \mathrm{a} \pm 2.7$ & $14.66 \mathrm{a} \pm 2.27$ \\
\hline
\end{tabular}

Means followed by the same letters on any one line, do not differ significantly at a confidence level of $95 \%$ ( $\leq 0,05)$. SD $=$ Standard Deviation 
Table 3 - Variance analysis of oil extraction from the cultivars

\begin{tabular}{|c|c|c|c|c|c|c|}
\hline \multirow{3}{*}{ Cause of variation } & \multicolumn{6}{|c|}{ Cultivar } \\
\hline & \multicolumn{2}{|r|}{ TMG1182RR } & \multicolumn{2}{|r|}{ M7578RR } & \multicolumn{2}{|r|}{ M9144RR } \\
\hline & GL & Mean square of Variable & GL & Mean square of Variable & GL & Mean square of Variable \\
\hline Time $(\mathrm{t})$ & 2 & $3.533^{*}$ & 2 & $2.422 *$ & 2 & $3.064 *$ \\
\hline Temperature $(\mathrm{T})$ & 2 & $7.389^{*}$ & 2 & $4.39 *$ & 2 & $1.343^{*}$ \\
\hline Ratio Ethanol/Hexano (R) & 2 & $3.639 *$ & 2 & $1.053 *$ & 2 & $1.747 *$ \\
\hline$t^{*} \mathrm{~T}$ & 0 & $3.533^{*}$ & 0 & $2.422 *$ & 0 & $3.064 *$ \\
\hline$t * R$ & 0 & $3.533^{*}$ & 0 & $2.422 *$ & 0 & $3.064 *$ \\
\hline $\mathrm{T} * \mathrm{R}$ & 0 & $7.389^{*}$ & 0 & $4.39 *$ & 0 & $1.343^{*}$ \\
\hline $\mathrm{t}^{*} \mathrm{~T} * \mathrm{R}$ & 2 & $3.962 *$ & 2 & $4.15^{*}$ & 2 & $1.565^{*}$ \\
\hline Error & 18 & 0.1656 & 18 & 0.676 & 18 & 0.153 \\
\hline $\mathrm{CV}(\%)$ & & 1.63 & & 3.32 & & 1.54 \\
\hline General mean & 24.9 & & 24.728 & & 25.4607 & \\
\hline
\end{tabular}

*Significant at $5 \%$

Figure 1 - Response Surface for oil extraction yield in the soybean cultivar TMG1182RR. (a) Temperature $\left({ }^{\circ} \mathrm{C}\right) \mathrm{x}$ Time (min), (b) Ethanol/Hexane Ratio x Time (min), (c) Ethanol/Hexane Ratio x Temperature $\left({ }^{\circ} \mathrm{C}\right)$

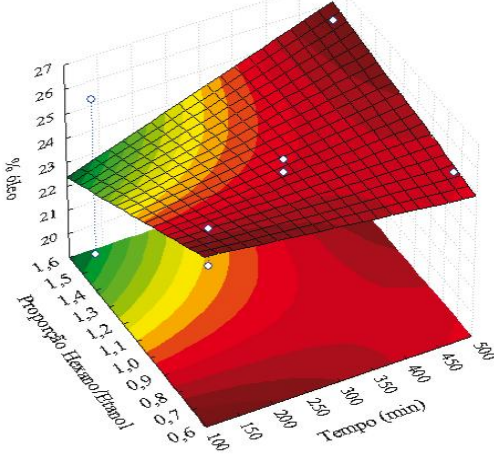

(a)

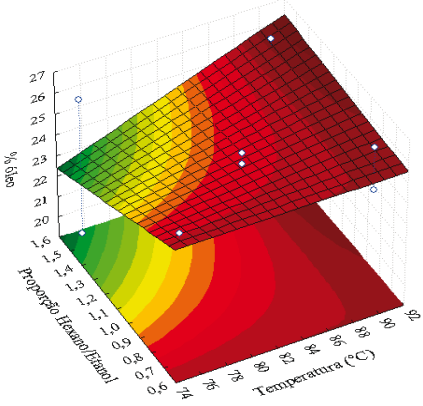

(b)

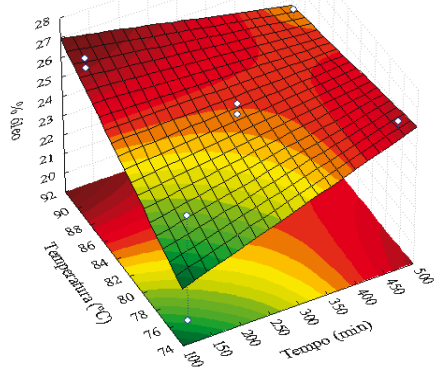

(c) 
Figure 2 - Response Surface for oil extraction yield in the soybean cultivar M7578RR. (a) Ethanol/Hexane Ratio x Time (min), (b) Ethanol/Hexane Ratio x Temperature $\left({ }^{\circ} \mathrm{C}\right),(\mathrm{c})$ Temperature $\left({ }^{\circ} \mathrm{C}\right) \mathrm{x}$ Time (min)

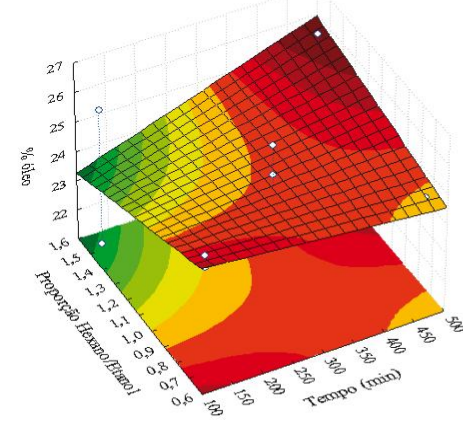

(a)

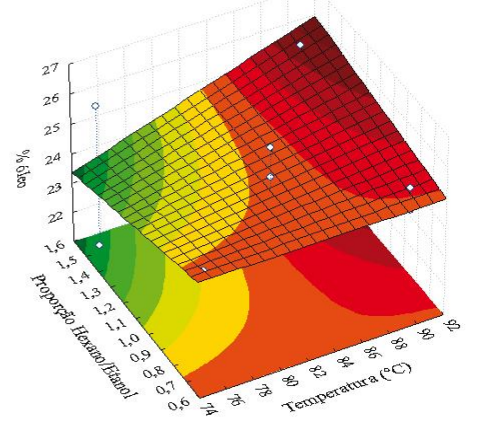

(b)

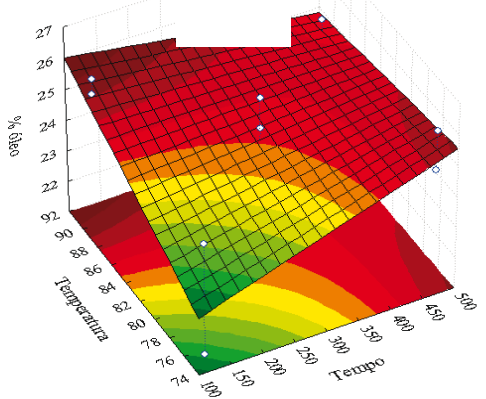

(c)

Tomazin Junior (2008) states that the best efficiency when extracting oil using ethanol takes place in the anhydrous concentration, since at this temperature there is a decrease in oil viscosity and an increase in solubility, allowing the ethanol-oil interaction and carrying the oil out of the cell.

The adjusted models can be seen in Table 4 . The suitability of the complete models can be checked by the coefficients of determination $\left(\mathrm{R}^{2}\right)$, which explain between 75 to $95 \%$ of the total variance of the response. Because of these results, the complete models were used to predict the behaviour of the responses within the studied variation range, with the independent variables that do not appear in the surface charts being fixed at their respective midpoints.

Figure 4 shows the Pareto charts obtained with the experimental design. The effect on yield becomes more significant the further it is to the right of the red line. It was seen that the interactions of time and temperature and of time and Ethanol/Hexane ratio was the most influential variable in the oil extraction process for the TMG 1182RR cultivar. Furthermore, the positive value for the coefficients makes it possible to state that the relationship is direct, i.e. the greater the interaction of these variables, the greater the levels of extracted oil. Oliveira et al. (2012) found similar results when attesting to the efficiency of using ethanol as an extraction solvent for rice bran oil. Some authors, such as Brum, Arruda and Regitano-D'arce (2009); Cerutti et al. (2012); Correia (2009); Freitas et al. (2010) and Gandhi et al. (2003), describe the existence of a series of solvents, mixtures and methods which can be used for extracting oil from grain, however the authors highlight the importance of taking into consideration some stages of the extraction process, such as solvent recovery, and the boiling process.

Navarro et al. (2007) point out that solvents differ in their extraction capacity according to the difference in polarity; the choice should be made with caution. The 
Figure 3 - Response Surface for oil extraction yield in the soybean cultivar M9144RR. (a) Ethanol/ Hexane Ratio x Time (min), (b) Temperature $\left({ }^{\circ} \mathrm{C}\right) \mathrm{x}$ Time (min), (c) Ethanol/Hexane Ratio x Temperature $\left({ }^{\circ} \mathrm{C}\right)$

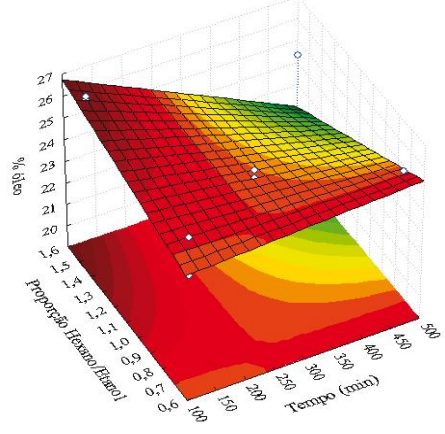

(a)

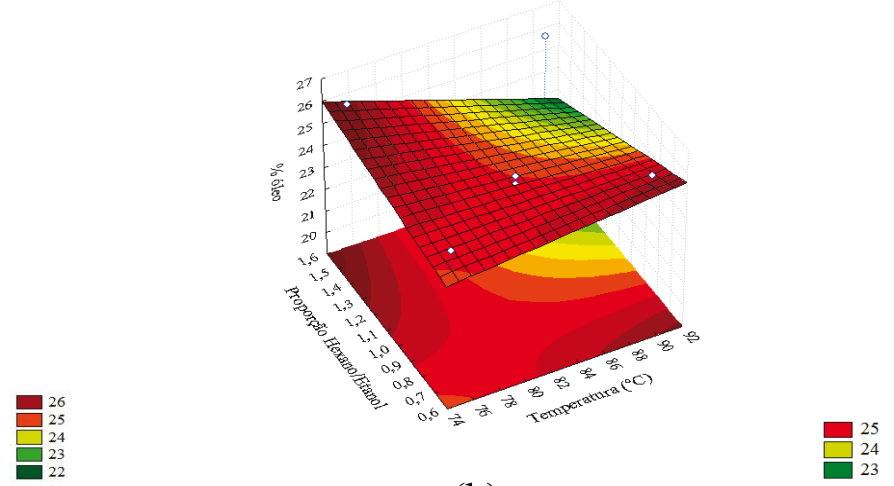

(b)

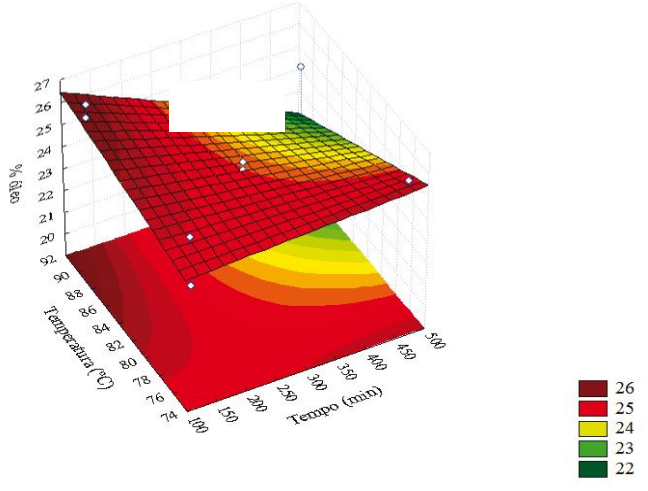

(c)

Table 4 - Regression equations with coded variables and coefficients of determination of the complete response models for \% soybean oil extracted

\begin{tabular}{lccc}
\hline \multicolumn{1}{c}{ Soybean } & Estimation Model & $\mathrm{R}^{2}$ \\
\hline TMG1182RR & $17.8602+0.0631 \mathrm{X} 1+0.1398 \mathrm{X} 2-22.6445 \mathrm{X} 3-0.0009 \mathrm{X} 1 \mathrm{X} 2+0.0124 \mathrm{X} 1 \mathrm{X} 3+0.2138 \mathrm{X} 2 \mathrm{X} 3$ & 0.90 \\
M7578RR & $21.0893+0.0376 \mathrm{X} 1+0.0751 \mathrm{X} 2-14.9174 \mathrm{X} 3-0.0005 \mathrm{X} 1 \mathrm{X} 2+0.0086 \mathrm{X} 1 \mathrm{X} 3+0.1450 \mathrm{X} 2 \mathrm{X} 3$ & 0.75 \\
M9144RR & $-11.0575+0.0671 \mathrm{X} 1+0.4083 \mathrm{X} 2+23.3286 \mathrm{X} 3-0.0007 \mathrm{X} 1 \mathrm{X} 2-0.0134 \mathrm{X} 1 \mathrm{X} 3-0.2427 \mathrm{X} 2 \mathrm{X} 3$ & 0.95 \\
\hline
\end{tabular}

author also points out that the use of an apolar solvent such as hexane for example, allows extraction of all the lipids present in the grain, however when mixed with a polar solvent such as ethanol, the mixture promotes pre-refining, that is, it allows purification of the oil for a few of the less apolar elements that are able to migrate to the polar phase.

The partial substitution of hexane by ethanol in oil extraction is discussed by Tomazin Junior (2008). In his study, the author states that use of a binary extraction mixture meets environmental demands, as it reduces the use of hexane, which is directly tied to the oil industry. Other relevant characteristics of hexane are highlighted by Guarienti et al. (2012), such as toxicity and flammability, which make its considered use or replacement, however partial, extremely important.

For the M7578RR cultivar, none of the variables was shown to be influential in the Pareto chart (Figure 4). 
Figure 4 - Pareto Chart for the soybean crops. (a) TMG1182RR (b) M7578RR (c) M9144RR

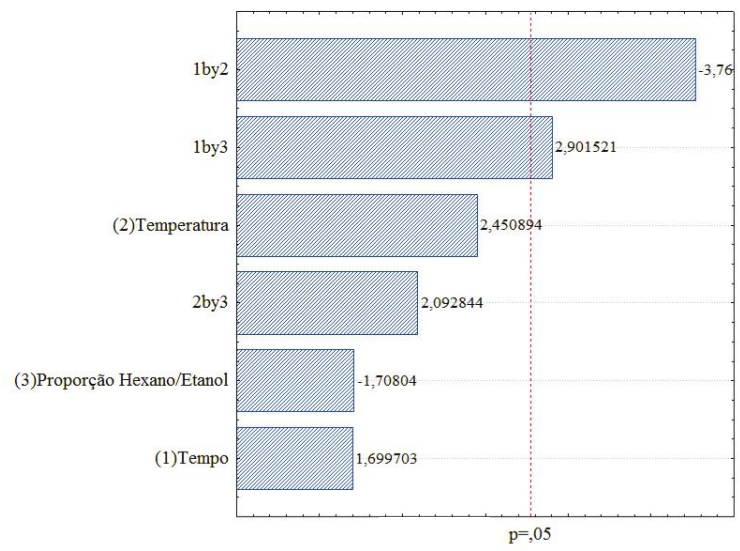

(a)

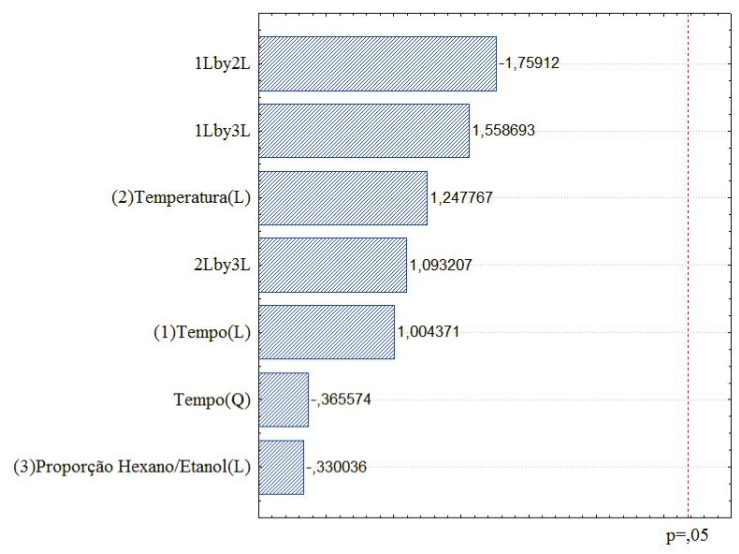

(b)

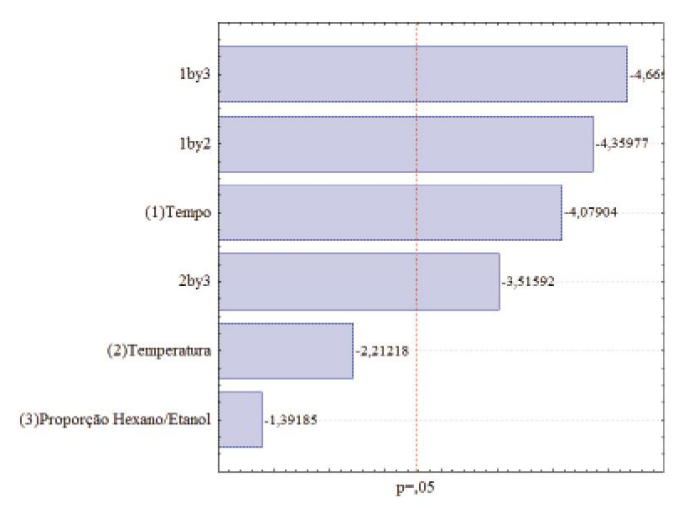

(c)

However, the positive coefficients for both time and temperature indicate that the larger the values of these variables, the greater the levels of oil extracted. For the M9144RR cultivar however, the extraction time, and the interactions of time and temperature and of time and ethanol/hexane ratio were seen to exert more interference, agreeing with the indications of the variance analysis (Table 3).

The relationship of that variable with extraction yield occurs in such a way that an increase in time causes an increase in the levels of extracted oil. Similar results were observed by Perez, Carelli, and Crapiste (2011) in the extraction of sunflower seed oil, where those authors noted that an increase in extraction time increased the amount of oil extracted. Santos et al. (2012) argue that extraction techniques aim at the maximum recovery of lipids from oilseeds, stimulating an intense search for optimal conditions, involving a reduction in costs and in processing time, but without losses in extracted oil yield.

\section{CONCLUSIONS}

1. The cultivars under study showed great potential as regards their protein and lipid components;

2. The use of a greater quantity of ethanol in the binary mixture causes an increase in the levels of extracted oil;

3. An increase in temperature contributes to that of the extraction process, having a direct impact on yield. The three variables studied are important in optimising the extraction of soybean oil. 


\section{REFERENCES}

BEHRENS, J. H.; DA SILVA, M. A. A. P. Atitude do consumidor em relação à soja e produtos derivados. Ciência e Tecnologia de Alimentos, v. 24, n. 3, p. 431-439, 2004.

BOX, G. E. P.; DRAPER, N. R. Empirical model-building and response surfaces. New York: Wiley, 1987. 669 p.

BRASIL. MINISTÉRIO DA AGRICULTURA, PEQUÁRIA E ABASTECIMENTO. Culturas: Soja. Disponível em: <http://www. agricultura. gov.br/vegetal/culturas/soja.> Acesso em: 16 dez. 2011.

BRASIL. CONSELHO NACIONAL DO ABASTECIMENTO. Acompanhamento da safra brasileira: safra 2012/2013. Disponível em: <http://www.conab.gov.br/OlalaCMS/ uploads/ arquivos/13_06_06_09_09_27_boletim_graos_-_junho_2013. pdf>. Acesso em: 06 dez. 2013.

BRUM, A. A. S.; ARRUDA, L. F.; REGITANO-D'ARCE. Métodos de extração e qualidade da fração lipídica de matérias-primas de origem vegetal e animal. Revista Química Nova, v. 13, n. 1, p. 849-854, 2009.

CARVALHO, W. T. et al. Características físico-químicas de extratos de arroz integral, quirera de arroz e soja. Pesquisa Agropecuária Tropical, v. 41, n. 3, p. 422-429, 2011.

CERUTTI, M. L. M. N. et al. Solvent extraction of vegetable oils: Numerical an experimental study. Food and Bioproducts Processing, v. 90, n. 2, p. 199-204, 2012.

CORREIA, I. M. S. Extração e pirólise do óleo de girassol (Helianthus annus $\mathbf{L}$.) visando a produção de biocombustíveis. 2009. 94 f. Dissertação (Mestrado em Engenharia Química) Departamento de Engenharia Química, Universidade Federal do Rio Grande do Norte, Natal, 2009.

FREITAS, R. F. S. et al. Contribuição ao estudo da extração do óleo do pinhão manso. In: CONGRESSO BRASILEIRO DE MAMONA E SIMPÓSIO INTERNACIONAL DE OLEAGINOSAS ENERGÉTICAS, 4., 2010, João Pessoa. Anais... João Pessoa: Embrapa Algodão, 2010. p. 1859-1865.

GANDHI, A. P. et al. Studies on alternative solvents for the extraction of oil soybean. International Journal of Food Science and Technology, v. 38, n. 3, p. 369-375, 2003.

GOMES, P. F. Curso de estatística experimental. Piracicaba: FEALQ, 2000. 477 p.

GUARIENTI, E. P. et al. Perdas de matéria-prima: um estudo de caso na indústria de óleo de soja. Engevista, v. 14. n. 1, p. $58-73,2012$.
INSTITUTO ADOLFO LUTZ. Métodos químicos e físicos para análise de alimentos. São Paulo: IMESP, 2005. 1018 p.

MARTINEZ, A. P. C. et al. Alterações químicas em grãos de soja com a germinação. Revista Ciência e Tecnologia de Alimentos, v. 31, n. 1 , p. $23-30,2011$

MOURA, N. C. et al. Composição de cultivares de soja submetida a diferentes tratamentos térmicos. Revista Alimentos e Nutrição, v. 18, n. 2, p. 151-160, 2007.

NAVARRO, F. M. S. et al. Estudo da solução de solventes na desacidificação do óleo de farelo de arroz: extração líqui-líquido. Scientia Plena, v. 3, n. 1, p. 1-5, 2007.

NIMET, G. et al. Extraction of sunflower (Heliantus annuus L.) oil with supercritical $\mathrm{CO} 2$ and subcritical propane: Experimental and modeling. Chemical Engineering Journal. v. 168, p. 262268, 2011.

OLIVEIRA, R. et al. Effects of the extraction conditions on the yield and composition of Rice bran oil extracted with ethanol - A response surface approach. Food and Bioproducts Processing, v. 90, n. 1, p. 22-31, 2012.

PELÚZIO, J. M. et al. Adaptabilidade e estabilidade de cultivares de soja em quatro épocas de semeadura no sul do estado do Tocantins. Revista Ceres, v. 55, n. 1, p. 34-40, 2008.

PEREIRA, M. J. Z. et al. BRS: 8990RR: Cultivar de soja indicada para o Maranhão, Piauí e Tocantins. In: CONGRESSO BRASILEIRO DE SOJA, 6., 2012, Cuiabá. Anais... Cuiabá: Embrapa, 2012. p. 1-5.

PEREZ, E. E.; CARELLI, A. A.; CRAPISTE, G. H. Temperaturedependent diffusion coefficient of oil from different sunflower seeds during extraction with hexane. Journal of Food Engineering, v. 105, n. 1, p. 180-185, 2011.

SANTOS, O. V. et al. Chemical evaluation and thermal behavior of Brazil nut oil obtained by different extraction processes. Food Research International, v. 47, n. 2, p. 253 $258,2012$.

TOMAZIN JUNIOR, C. Extração de óleo de soja com etanol e transesterificação etílica na miscela. 2008. 72 f. Dissertação (Mestrado em Ciências) - Centro de Energia Nuclear da Agricultura, Universidade de São Paulo, Piracicaba, 2008.

ZACHI, R. Influência da temperatura no processo de extração de óleo de soja em leito fixo. 2007. 115 f. Dissertação (Mestrado em Modelagem Matemática) - Departamento de Física, Estatística e Matemática, Universidade Regional do Noroeste do Estado do Rio Grande do Sul, Ijuí, 2007. 